\title{
INFLUENCE OF EXOGENOUS ENZYMES SUPPLEMENTATION ON IN VITRO RUMINAL FERMENTATION AND PRODUCTIVE PERFORMANCE OF SHEEP
}

\author{
A.A. Marwan ${ }^{1}$ and A.M. Singer ${ }^{2}$ \\ ${ }^{1}$ Animal Production Dept., Fac. of Agric., Ain Shams Univ., Egypt. \\ ${ }^{2}$ Animal Production and Poultry Dept., Fac. of Agric., Aswan Univ., Egypt.
}

(Received 1/11/2018, accepted $18 / 12 / 2018$ )

SUMMARY

$\mathrm{T}$

his study was conducted in Animal Production Department Farm, Faculty of Agriculture, Ain Shams University, Shoubra El Kheima, Kalubeya Province, Egypt. This study was performed to compare the influence of different doses of enzymes (ZAD) in liquid form (ZL) on productive performance of Barki sheep. Twenty growing Barki sheep aged between 7-8 months with average body weight $43.4 \mathrm{~kg}$ BW were used in 75 days growth trial. Animals were divided into four treatments, T1; were fed basic diet, T2; were fed basic diet plus $1.5 \mathrm{ml}$ orally dose of ZL/head/day.T3; were fed basic diet plus $2.5 \mathrm{ml}$ orally dose of $\mathrm{ZL} /$ head/day.T4; were fed basic diet plus $4 \mathrm{ml}$ orally dose of ZL/head/day. The results demonstrated that the Barki sheep received $4 \mathrm{ml} Z \mathrm{~L}$ had better performance $(\mathrm{P} \leq 0.05)$ in total gain by $28.45 \%$, ADG by $28.65 \%$ than the control group (without $\mathrm{ZL}$ ). Results of In vitro gas production trial showed a significant $(\mathrm{P} \leq 0.05)$ positive effects of ZL on DMD, OMD and CPD. Also, ZL had a significant positive effects on all rumen parameters. Concerning productive performance results, in General, Barki sheep orally ZL dose showed significant improvement $(\mathrm{P} \leq 0.05)$ in the values of dry matter intake and dry matter conversion compared with control group. The mean values of plasma total protein, globulin and GPT concentrations had higher values $(\mathrm{P} \leq 0.05)$ for animals received $4 \mathrm{ml} \mathrm{ZL}$ than control group, while triglyceride and GOT levels in all groups remained relatively stable throughout the study. All blood parameters were being within normal range. In conclusion, use exogenous enzymes in liquid form to Barki sheep at dose (4 ml ZL) had positive and beneficial effects on enhance dry matter intake, dry matter conversion, average daily gain and total gain.

Keywords: ZAD, liquid form dose, In vitro gas production, Barki sheep, Blood parameters and growth performance.

\section{INTRODUCTION}

Numerous endeavors in the field of animal nutrition are being done to accomplish enhance in animal production and thereby benefit. Feed additives are imperative materials that can enhance the efficiency of feed usage and animal productivity (Abdou, 2001).

Probiotics were defined as live microorganisms that might having a beneficially effect on the host upon ingestion, by enhancing the natural balance of ruminal microflora (FAO/WHO, 2002), ruminant productive responses (Tripathi and Karim 2011) improve health, performance and growth rates (Bohm and Srour 1995). vitamins and proteins synthesis, calcium absorption, stimulations and augment the immune system (Cross ML, 2002), improved ratio of feed conversion in small ruminants (Robinson PH, 2002) and stimulating role on intake of DM and fiber degradability (Chademana and Offer, 1990).

Some probiotics having positive advantages on animal's performance and immunity. The valuable impacts of probiotic might be interceded by a direct antagonistic effect against specific organisms (Fuller, 1977; Wathins, 1982 and Hentages 1993) or by stimulation of immunity (Umesb, 1999). In addition, Consideration probiotic in sheep diets improved lamb performance (Ali, 2005, Abbas, 2005 and Hassan and Hassan 2008) and increased live weight gain (Orr et al., 1988 and Galyean et al., 2000). Also improves nutrients digestibility and feed conversion ratio (El- Shaer, 2003). 
Supplementing animal diet's with fibrolytic enzymes can enhance feed utilization and animal productivity by improving fiber degradation (Gado et al., 2009); improving digestibility and feed intake (Gado and Salem, 2008; Krueger et al., 2008). Moreover, fibrolytic enzymes influence hydrolytic movement in the rumen to decrease gut fill and increase feed intake (Adesogan, 2005). It also improves microbial colonization of feed and rumen microbial protein combination by expanding quantities of ruminal fibrolytic organisms (Morgavi et al., 2000; Nsereko et al., 2000). Moreover, Fibrolytic enzymes can be also enhance ruminal fiber degradability rate (Yang et al., 1999; Giraldo et al., 2008).

The commercial product $\mathrm{ZAD}{ }^{\circledR}$ is an exogenous enzyme product, composed from anaerobic bacterium. It has been appeared to enhance fermentation of rumen, nitrogen balance and nutrients digestibility (Gado et al., 2007). Also, the conversion of feed and body weight gain can be improve by ZAD in goats and sheep (Gado and Salem 2008).

The objectives of this study were to investigate the impact of adding ZAD as a probiotic in ration of Barki lambs on blood metabolites, feed efficiency and growth performance.

\section{MATERIALS AND METHODS}

This study was conducted in Animal Production Department Farm, Faculty of Agriculture, Ain Shams University, Shoubra El Kheima, Kalubeya Province, Egypt.

\section{Feed additives composition and sources:}

\section{The ZAD liquid (ZL):}

The product $\mathrm{ZAD}{ }^{\circledR}$ is a probiotic, contains anaerobic bacteria and a mixture of natural enzymes as cellulase, xylanase, alpha amylase and protease in a balanced effective formula (Bactizad 2018).

\section{In vitro gas production technique:}

Twenty-four hours before beginning of the experiment, $500 \pm 5 \mathrm{mg}$ of sample for each treatment (contained clover hay as a roughage and concentrate at ratio of 40:60) was weighed into $125 \mathrm{ml}$ glass bottles. A solution of buffer was prepared before rumen fluid addition as described by Szumacher-Strabel et al. (2002) and flushed continuously with $\mathrm{CO} 2$ at $39{ }^{\circ} \mathrm{C}$ during sample inoculation. Rumen fluid was obtained from sheep using stomach tube $4 \mathrm{hrs}$ post feeding. Rumen fluid was mixed well into a bottle (1 Liter) with an $\mathrm{O} 2$-free headspace and immediately transported to laboratory at $39^{\circ} \mathrm{C}$. The rumen fluid was filtered through four layers of cheesecloth to eliminate large feed particles. The solution of buffer was prepared without urea to determine protein degradability then added to rumen fluid at ratio 4:1 and forty $\mathrm{ml}$ of this inoculum was added to all bottle, then $\mathrm{CO} 2$ was flushed to the headspace of each bottle and closed. The inoculums initial $\mathrm{pH}$ was from 6.8 to 6.9 .

\section{Degradability:}

Calculation of dry matter degradability (\% dDM) was the difference between the sample DM content and that in the residual after $24 \mathrm{~h}$ incubation / sample DM content $* 100$. Calculation of protein degradability $(\% \mathrm{dCP})$ was the difference between the content in the sample before and after incubation / content in the sample before incubation $* 100$.

\section{Total gas production:}

After $24 \mathrm{~h}$ of samples incubation, the total gas production (GP) was estimated by the displacement of syringe piston, which was connected to the serum flasks. The gas produced due to fermentation of substrate was calculated by subtracting gas produced in blank vessels (without substrate) from total gas produced in the vessels containing buffered rumen fluid and substrate.

\section{Calculation:}

Metabolizable energy (ME, Mcal/kg DM), In vitro organic matter digestibility (OMD, g/kg OM) were estimated according to (Menke and Steingass, 1988), short chain fatty acid (SCFA) concentrations were calculated according to Getachew et al. (2002), microbial biomass production (MCP) and efficiency of microbial biomass production (EMP) were calculated according to Blummel et al. (1997) as: - 


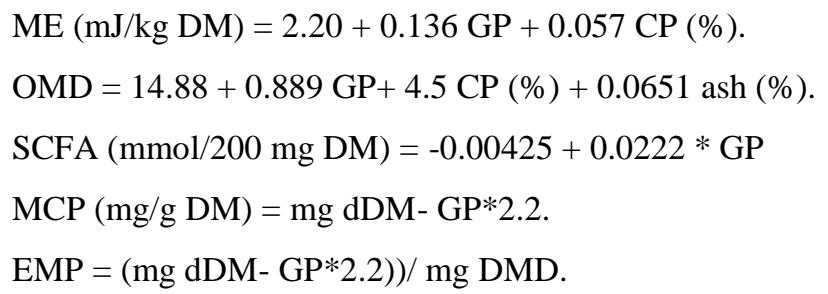

Where: GP is net gas production in $\mathrm{ml}$ from $200 \mathrm{mg}$ of dry sample after $24 \mathrm{~h}$ of incubation, $2.2 \mathrm{mg} / \mathrm{ml}$ is a stoichiometric factor that expresses $\mathrm{mg}$ of $\mathrm{C}, \mathrm{H}$, and $\mathrm{O}$ required for the SCFA gas associated with production of $1 \mathrm{ml}$ of gas.

After 24 hrs. of incubation, the filtrated rumen liquor for each sample was subjected for further investigation. The $\mathrm{pH}$ of rumen fluid was measured by $\mathrm{pH}$ meter while samples were stored at $-20^{\circ} \mathrm{C}$ until chemical analysis. Ruminal ammonia nitrogen (NH3-N) concentration was determined according to Conway (1957), Ruminal total volatile fatty acids (TVFA's) concentration was determined by steam distillation procedure according to Warner (1964).

\section{The experimental animals and rations:}

Twenty growing Barki sheep of 7-8 months old and weighing on average $43.4 \mathrm{~kg}$ BW were used in 75 days Growth trial. Animals were divided in to four groups (5 animals each) to study the effect of adding ZAD as a probiotic on animal performance. Each group was assigned randomly to feed on one of the following four dietary treatments:

T1; were fed according to the feeding regime of the farm system (NRC, 1985).

$\mathrm{T} 2$; were fed as T1 plus $1.5 \mathrm{ml}$ orally dose of ZL/head/day.

T3; were fed as T1 plus $2.5 \mathrm{ml}$ orally dose of ZL/head/day

T4; were fed as T1 plus $4 \mathrm{ml}$ orally dose of ZL/head/day

Animals of the first group (T1, the control group) was fed according to the traditional allowances of the experimental farm station (Basal Ration). These animals were fed on a ration containing concentrate feed mixture (CFM) and Alfalfa hay as 1:1.5 on DM basis.

Sheep of the second, third and fourth group (T2, T3 and T4 group, the treated groups) were fed according to the traditional allowances of the experimental farm station (as that of the first group, T1) plus $1.5,2.5$ and $4 \mathrm{ml} \mathrm{ZL/head/day,} \mathrm{for} \mathrm{T2,} \mathrm{T3} \mathrm{and} \mathrm{T4,} \mathrm{respectively.}$

The experiment was extended for eleven weeks since the animals introduced to the treatment, experimental data was collected during entire this period. Chemical compositions of feed stuffs are represented in Table (1).

Table (1): Chemical composition of the experimental feed stuffs ( $\%$ on DM basis).

\begin{tabular}{lccccccc}
\hline Item & DM & OM & CF & CP & EE & NFE & Ash \\
\hline Concentrate feed mixture & 89.00 & 86.52 & 17.98 & 12.81 & 4.49 & 51.24 & 13.48 \\
Alfalfa hay & 87.00 & 79.31 & 34.94 & 11.61 & 2.87 & 29.88 & 20.69 \\
\hline
\end{tabular}

\section{Blood samples:}

At the end of experiment, blood samples were taken from each animal in all treatments. The blood samples were taken at three hours post morning feeding. A sample of $15 \mathrm{ml}$ of blood per animal was withdrawn from the jugular vein and directly collected into a clean dried glass culture tubes after adding EDTA. The blood plasma was obtained by centrifuging the blood samples soon after collection at 4000 (rpm) for 15 minutes. Blood plasma was transferred into a clean dried glass vials andthen stored in deep freezer at $-20^{\circ} \mathrm{C}$ for subsequent specific chemical analysis. 


\section{Productive performance parameters:}

Live body weights were individually recorded at two weeks' intervals. The average daily body weight gain was individually calculated. Daily feed intake was determined for each replicate of a treatment by the difference between the daily offered feed and the daily residual one. Feed conversion ratios were obtained by dividing the amount of feed consumption per sheep by the corresponding weight gain in a certain stage (two weeks).

\section{Analytical methods:}

The chemical composition of the feedstuffs and feaces were analyzed according to the A.O.A.C (1995) methods to determine moisture, DM, OM, CP, CF, EE, and ash contents, while NFE content was calculated by difference. Blood plasma was analyzed for total protein (Armstrong and Carr, 1964). Albumin (Doumas et al., 1971), urea (March, 1965), creatinine (Husdan, 1968), GPT and GOT (Reitman and Frankel, 1957), triglyceride (Fassati P., 1982), while globulin was calculated by difference.

\section{Statistical Analysis:}

The data were analyzed according to statistical analysis system (SAS) User s Guide (2001). Separation among means was carried out by using Duncan multiple tests, (1955).

\section{RESULTS AND DISCUSSION}

In general, the present results of the chemical composition values of CFM, Berseem, rice straw (Table, 1) are within the normal ranges reported in Egypt by several workers (Baraghit et al., 1995 and El-Hosseiny et al., 2008).

\section{In vitro gas production trial:}

Within treatments, a significant increase $(\mathrm{P} \leq 0.05)$ in $\mathrm{DM}$ and $\mathrm{OM}$ degradability after 24 hours was recorded for all rations supplemented with $\mathrm{ZL}$. The highest values of DM and OM degradability was recorded for dose $4 \mathrm{ml} \mathrm{ZL}$ (Table 2). Also, these results showed a positive effect of ZL on CP degradability against control group (without ZL). These results in a good agreement with those obtained by Soliman et al. (2016) when they fed Barki sheep on a ration supplemented by probiotic, they found a significant improvement on DM, OM and CP digestibility coefficients.

Many studies have pointed that the addition of probiotic (DFM) increased the in vitro dry matter digestibility (IVDMD) and in vitro organic matter digestibility values (IVOMD) cited by Hutjens (2005).

Gomez-Basauri et al. (2001) evaluated the effect of a supplement DFM on apparent digestibility. They found that cows fed ration supplemented with DFM increased digestibility of OM, DM, CP and CF compared with those fed control ration. Also, other researchers found that Probiotics improved nutrient digestibility (Abd El-Ghani, 2004). In addition, Krehbiel et al. (2003) reported that feed additives of probiotic (DFM) improved the CP and CF digestibilities of the diets.

Supplementing ration with ascending level of $\mathrm{ZL}$ had no significant effect on ammonia concentration $(\mathrm{mg} / 100 \mathrm{ml})$ (Table 2).The data showed that A significant increase $(\mathrm{P} \leq 0.05)$ on $\mathrm{pH}$ value, total volatile fatty acids (meq $/ 100 \mathrm{ml}$ ), microbial protein MP (mg/100 ml rumen liqour), efficiency of microbial protein EMP, short chain fatty acid SCFA $(\mu \mathrm{m})$ and metabolizable energy ME $(\mathrm{Mcal} / \mathrm{g})$. These results clearly indicate that supplementing zad liquid (ZL) on ration may be have a positive effect on rumen fermentation parameters.

These positive progress may be due to ZL effect on bacteria activity which increased growth and activity ruminal bacteria and causes increase protein degradation (Table 2). Several studies have proposed that the needs of rumen microbes to perform its activity were provided by relative stability of $\mathrm{pH}$ during fermentation due to increasing $\mathrm{pH}$ and lactate utilization (Elghandour et al., 2014).

The gas production (GP) had a higher values with ration supplemented by ZL, these finding clearly revealed that the increased gas production (GP) was a result of increased adding of zad liquid to ration. It is well known that microorganisms has the ability to increase ammonia production in the rumen (Hristov et al., 2013) by increased protein degradation and increased the overall $\mathrm{N}$ excretion by the animal. 
Table (2): Effect of experimental treatments on kinetics of gas production, rumen fermentation and degradability of DM, OM, and protein after 24 hours on DM basis.

\begin{tabular}{|c|c|c|c|c|}
\hline \multirow{2}{*}{ Item } & \multicolumn{4}{|c|}{ Treatment } \\
\hline & $\mathrm{T} 1$ & $\mathrm{~T} 2$ & T3 & $\mathrm{T} 4$ \\
\hline \multicolumn{5}{|l|}{ Degradability } \\
\hline DMD $\%$ & $48.40^{\mathrm{B}}$ & $51.73^{\mathrm{AB}}$ & $53.07^{\mathrm{A}}$ & $54.67^{\mathrm{A}}$ \\
\hline OMD $\%$ & $41.56^{\mathrm{B}}$ & $43.037^{\mathrm{AB}}$ & $42.365^{\mathrm{AB}}$ & $43.57^{\mathrm{A}}$ \\
\hline $\mathrm{CPD} \%$ & 34.52 & 35.46 & 37.05 & 36.29 \\
\hline \multicolumn{5}{|c|}{ Gas production $\mathrm{ml} / 200 \mathrm{mg} \mathrm{DM}$} \\
\hline GP after $24 \mathrm{hr}$ & $62.67^{\mathrm{B}}$ & $66.33^{\mathrm{AB}}$ & $64.67^{\mathrm{AB}}$ & $67.67^{\mathrm{A}}$ \\
\hline GP/hour & $5.92^{\mathrm{B}}$ & $6.27^{\mathrm{AB}}$ & $6.11^{\mathrm{AB}}$ & $6.39^{\mathrm{A}}$ \\
\hline \multicolumn{5}{|l|}{ Rumen parameters } \\
\hline $\mathrm{pH}$ & $6.70^{\mathrm{B}}$ & $6.83^{\mathrm{A}}$ & $6.87^{\mathrm{A}}$ & $6.80^{\mathrm{AB}}$ \\
\hline NH3 (mg/100ml) & 16.12 & 19.34 & 23.08 & 18.79 \\
\hline TVF's (meq/100ml) & $6.45^{\mathrm{B}}$ & $6.63^{\mathrm{B}}$ & $7.00^{\mathrm{A}}$ & $6.62^{\mathrm{B}}$ \\
\hline MP & $110.70^{\mathrm{B}}$ & $116.36^{\mathrm{AB}}$ & $113.79^{\mathrm{AB}}$ & $118.41^{\mathrm{A}}$ \\
\hline EMP & $26.64^{\mathrm{B}}$ & $27.03^{\mathrm{AB}}$ & $26.86^{\mathrm{AB}}$ & $27.17^{\mathrm{A}}$ \\
\hline SCFA & $3.15^{\mathrm{B}}$ & $3.34^{\mathrm{AB}}$ & $3.25^{\mathrm{AB}}$ & $3.40^{\mathrm{A}}$ \\
\hline M E Mcal/g DM & $2.92^{\mathrm{B}}$ & $2.97^{\mathrm{AB}}$ & $2.95^{\mathrm{AB}}$ & $2.99^{\mathrm{A}}$ \\
\hline
\end{tabular}

T1; Control, T2; Control plus $1.5 \mathrm{ml}$ orally dose of ZL/head/day, T3; Control plus $2.5 \mathrm{ml}$ orally dose of ZL/head/day and T4; Control plus $4 \mathrm{ml}$ orally dose of ZL/head/day. $Z L=Z A D$ liquid.

$A$ and $B$ Means of treatments within the same row with different superscript letters are significantly different $(P \leq 0.05)$. MP: microbial protein ( $\mathrm{mg} / 100 \mathrm{ml}$ rumen liqour) - EMP: efficiency of microbial protein - SCFA: short chain fatty acid ( $\mu \mathrm{m})$. ME : metabolic energy (Mcal/g DM).

Results showed improve on ME, MP, and GP 24 with the ration supplanted by ZL, this reflect a high protein content which provide the essential nutrients for ruminal microflora activity. The highly ruminal microflora activity reflected on higher gas production (GP), highly synthesis of microbial protein and higher degradability. These findings are agreement with those reported by Soliman et al. (2016) when they fed Barki sheep on a ration supplemented by probiotic.

\section{Productive performance:}

Dry matter intake $(\mathrm{kg} / \mathrm{h} / \mathrm{d})$ :

Data presented in Table (3) showed that the intake of dry matter is increased by increasing the dose

Table (3): Effect of experimental treatments on dry matter intake (kg/h/d)

\begin{tabular}{lcccc}
\hline \multirow{2}{*}{ Days } & \multicolumn{4}{c}{ Treatments } \\
\cline { 2 - 5 } & $\mathrm{T} 1$ & $\mathrm{~T} 2$ & $\mathrm{~T} 3$ & $\mathrm{~T} 4$ \\
\hline $0-15$ & $1.52 \pm 0.04$ & $1.47 \pm 0.07$ & $1.56 \pm 0.03$ & $1.53 \pm 0.02$ \\
$16-30$ & $1.59 \pm 0.05$ & $1.58 \pm 0.06$ & $1.66 \pm 0.03$ & $1.62 \pm 0.02$ \\
$31-45$ & $1.67 \pm 0.05$ & $1.68 \pm 0.06$ & $1.77 \pm 0.03$ & $1.73 \pm 0.01$ \\
$46-60$ & $1.76 \pm 0.05$ & $1.78 \pm 0.06$ & $1.88 \pm 0.03$ & $1.84 \pm 0.01$ \\
$61-75$ & $1.85 \pm 0.06$ & $1.87 \pm 0.07$ & $1.98 \pm 0.03$ & $1.96 \pm 0.01$ \\
Average & $1.68^{\mathrm{B}}$ & $1.69^{\mathrm{B}}$ & $1.77^{\mathrm{A}}$ & $1.74^{\mathrm{A}}$ \\
\hline
\end{tabular}

T1; Control, T2; Control plus $1.5 \mathrm{ml}$ orally dose of ZL/head/day, T3; Control plus $2.5 \mathrm{ml}$ orally dose of ZL/head/day and T4; Control plus $4 \mathrm{ml}$ orally dose of ZL/head/day. $Z L=Z A D$ liquid.

$A$ and $B$ Means of treatments within the same row with different superscript letters are significantly different $(P \leq 0.05)$. 
of ZL plus basic rations and may be due to increased fiber digestion. The highest value of dry matter intake was recorded with dose $4 \mathrm{ml} \mathrm{ZL}(1.74 \mathrm{Kg} / \mathrm{h} / \mathrm{d})$ while the lowest one was recorded with basic rations without $\mathrm{ZL}(1.68 \mathrm{Kg} / \mathrm{h} / \mathrm{d})$. The significant different was observed between the dose $1.5 \mathrm{ml} \mathrm{ZL}$ and the dose $4 \mathrm{ml} \mathrm{ZL}$ while no different significant was observed between the dose $1.5 \mathrm{ml} \mathrm{ZL}$ and basic ration without ZL. These data are in agreement with Nocek et al. (2003) who observed that an increased in dry matter intake $(2.6 \mathrm{~kg} / \mathrm{day})$.

\section{Blood plasma parameters:}

The data of blood plasma parameters are shown in Table (4). Results showed that the animals fed basic rations plus higher dose of $\mathrm{ZL}$ recorded significantly $(\mathrm{P} \leq 0.05)$ the higher plasma total protein, albumin, globulin, urea and triglycerides compared basic rations without ZL. These findings are agreement with those reported by (Abu Elnour and Kholif, 1998 and Monika, et al., 2000) they reported that total protein levels in blood serum were increased due to use Saccharomyces cerevisiae yeast in the diet of suckling calves compared to the control treatment and pointed that it can be due to improved rumen microbial protein synthesis. Also, Gado et al., 2009 reported an increase in total protein, GPT for animals received ZAD.

Table (4): Effect of experimental treatments on some blood plasma parameters

\begin{tabular}{lcccc}
\hline \multirow{2}{*}{ Item } & \multicolumn{3}{c}{ Treatments } & $\mathrm{T} 3$ \\
\cline { 2 - 5 } & $\mathrm{T} 1$ & $\mathrm{~T} 2$ & $6.43^{\mathrm{AB}}$ & $6.61^{\mathrm{A}}$ \\
\hline Total protein(g/dl) & $5.42^{\mathrm{C}}$ & 3.70 & 4.12 & 3.73 \\
Albumin(g/dl) & 3.59 & $2.20^{\mathrm{AB}}$ & $2.31^{\mathrm{AB}}$ & $2.88^{\mathrm{A}}$ \\
Globulin $(\mathrm{g} / \mathrm{dl})$ & $1.82^{\mathrm{B}}$ & 39.02 & 41.47 & 42.43 \\
Urea(mg /dl) & 40.41 & $0.98^{\mathrm{AB}}$ & $0.91^{\mathrm{B}}$ & $0.93^{\mathrm{AB}}$ \\
Creatinine(g/dl) & $1.19^{\mathrm{A}}$ & 45.89 & 48.38 & 50.33 \\
Triglycerides (mg/dl) & 41.46 & 37.33 & 33.33 & 34.00 \\
GOT (unit/L) & 42.33 & $23.00^{\mathrm{AB}}$ & $22.00^{\mathrm{AB}}$ & $20.00^{\mathrm{B}}$ \\
GPT (unit/L) & $26.00^{\mathrm{A}}$ & & & \\
\hline
\end{tabular}

T1; Control, T2; Control plus $1.5 \mathrm{ml}$ orally dose of ZL/head/day, T3; Control plus $2.5 \mathrm{ml}$ orally dose of ZL/head/day and T4; Control plus $4 \mathrm{ml}$ orally dose of $Z \mathrm{Z} / \mathrm{head} / \mathrm{day} . \mathrm{ZL}=\mathrm{ZAD}$ liquid.

$A, B$ and $C$ Means of treatments within the same row with different superscript letters are significantly different $(P \leq$ 0.05).

Data of Table (4) showed that blood serum GPT and creatinine values were decreased by ZL received. These results are in an opposite trend by those of Kholif (2006) who found that animals fed on fibrolytic enzymes or fungi treated silage didn't record any significant change in blood serum GPT concentration compared with animals fed on silage without treatment. Also Kholif et al., (2012) found that exogenous supplemented rations were not significantly affected buffalo's blood serum AST.

Finally, the concentration plasma proteins, albumin, globulin, GOT, GPT, creatinine and triglyceride in the normal range of healthy animals. These data indicated that ZL supplemented to Barki sheep were not have negative effect on liver function or general animal's health.

\section{Body weight and Growth performance:}

Data of sheep's body weight are presented in Table (5). It could be observed that the Barki sheep given high dose of ZL showed the heaviest total gain followed by those gave low dose and then by the control group. The differences were significant $(\mathrm{P} \leq 0.05)$. It is worthy to note that there were insignificant differences in total gains between control lambs and lambs given low dose of ZL. Animals given high dose of ZL (4 ml) showed the highest gain $(15.8 \mathrm{Kg})$ followed by those given $2.5 \mathrm{ml}(15.10 \mathrm{~kg}), 1.5 \mathrm{ml}$ ZL $(14.40 \mathrm{~kg})$ and then by the $0 \mathrm{ml}$ ZL $(12.30 \mathrm{~kg})$. The present results illustrate that total gain of sheep with the dose $4 \mathrm{ml}$ ZL was increased by $28.46 \%$ of the control group $(0 \mathrm{ml} \mathrm{ZL})$. It could be noticed that dose $4 \mathrm{ml}$ of $\mathrm{ZL}$ is more efficient than the dose of $0 \mathrm{ml}$ of $\mathrm{ZL}$.

The present results are supported by the results of Russell and Wilson (1996) who reported that response of lambs to probiotic supplementation may be due to improving degradability of fiber. Higher feed consumption and utilization was shown as a result to adding probiotic (Antunovic et al., 2006). 
These data are in agreement with Sarwar et al., 2010) they showed that use of probiotic improved weight gain of growing lambs. These results are also in agreement with many researches those reported by Mukhtar et al., (2010) and Khalid et al.,(2011) whose they reported that lambs fed diets with probiotic had improved weight gain and they pointed out that improving may be depending upon probiotic rate or level.

The Data of growth performance of Barki sheep inoculum graded doses of Exogenous Enzymes are shown in Table (5). Results showed that sheep inoculum dose $4 \mathrm{ml} Z \mathrm{~L}$ recorded significantly $(\mathrm{P} \leq 0.05)$ highest average daily gain $(0.211 \mathrm{~kg} / \mathrm{h} / \mathrm{day})$ as a result that the total gain $(15.80 \mathrm{Kg})$ was at the same line.

Table (5): Effect of experimental treatments on changes of body weights and daily gain $(\mathrm{kg} / \mathrm{h} / \mathrm{d})$.

\begin{tabular}{|c|c|c|c|c|}
\hline \multirow{2}{*}{ Item } & \multicolumn{4}{|c|}{ Treatments } \\
\hline & $\mathrm{T} 1$ & $\mathrm{~T} 2$ & T3 & $\mathrm{T} 4$ \\
\hline \multicolumn{5}{|l|}{ Animal weight } \\
\hline Initial weight & $43.30 \pm 1.22$ & $42.00 \pm 2.01$ & $44.50 \pm 0.76$ & $43.70 \pm 0.51$ \\
\hline Final weight & $55.60 \pm 1.47$ & $56.40 \pm 1.93$ & $59.60 \pm 1.11$ & $59.50 \pm 0.32$ \\
\hline Total gain & $12.30^{\mathrm{B}} \pm 0.30$ & $14.40^{\mathrm{AB}} \pm 0.81$ & $15.10^{\mathrm{A}} \pm 0.43$ & $15.80^{\mathrm{A}} \pm 0.25$ \\
\hline \multicolumn{5}{|c|}{ Average daily gain $(\mathrm{kg} / \mathrm{h} /$ day $)$} \\
\hline \multicolumn{5}{|l|}{ Days } \\
\hline $0-15$ & $0.140 \pm 0.02$ & $0.207 \pm 0.03$ & $0.193 \pm 0.03$ & $0.180 \pm 0.01$ \\
\hline $16-30$ & $0.160 \pm 0.02$ & $0.200 \pm 0.02$ & $0.213 \pm 0.02$ & $0.207 \pm 0.01$ \\
\hline $31-45$ & $0.167 \pm 0.01$ & $0.180 \pm 0.01$ & $0.207 \pm 0.02$ & $0.213 \pm 0.01$ \\
\hline $46-60$ & $0.173 \pm 0.01$ & $0.180 \pm 0.01$ & $0.193 \pm 0.01$ & $0.220 \pm 0.01$ \\
\hline $61-75$ & $0.180 \pm 0.02$ & $0.193 \pm 0.01$ & $0.200 \pm 0.01$ & $0.233 \pm 0.01$ \\
\hline Average & $0.164^{\mathrm{B}}$ & $0.192^{\mathrm{A}}$ & $0.201^{\mathrm{A}}$ & $0.211^{\mathrm{A}}$ \\
\hline
\end{tabular}

$A$ and $B$ Means of treatments within the same row with different superscript letters are significantly different $(P \leq 0.05)$.

These results are in an agreement with Jang et al., (2009) who found that using Probiotic supplementation in lambs improved weight gain. The improve in total gain of Barki sheep fed basal diet plus $4 \mathrm{ml} \mathrm{ZL}$ could be attributed to Production of amino acids, vitamins or other growth factors stimulatory to microflora in the digestive tract; increasing Immunomodulation of the animal (Isolauri et al., 2001); Production and stimulation of enzymes; Metabolism and/or detoxification of undesirable compounds. Many researchers explained the reasons for the increase in growth rate and improve weight gain as follows it could be due to improved synthesis of microbial protein which led to increase amino acids supply at post-ruminal level (Erasmus et al., 1992) or it might be as a result to increase consumption and better feed efficiency in incase of use of the probiotics in diets (Antunovic et al., 2006). Also, (Russell and Wilson, 1996) reported that the higher weight gain in ruminants during use probiotics in diets might be also due to more cellulolytic activity resulting in improved fiber degradation, because of reduced activity of more ammonia producing microbes that made the protein available for absorption at the post-ruminal level. At the same trend (Khalid et al., 2011) reported that the improvement in the average daily gain may be due to an improvement in microbial ecosystem, increase in nutrient bioavailability and improvement of growth performance in lambs received diets contain probiotics.

\section{Feed conversion (kg DM/ kg gain):}

The data of feed conversion of Barki sheep fed traditional rations plus different doses of ZL are shown in Table (6). Results showed that as the level of ZL was increased, the feed conversion was gradually improved. 
Table (6): Effect of experimental treatments on feed conversion ( $\mathrm{kg} \mathrm{DM} / \mathrm{kg}$ gain)

\begin{tabular}{lcccc}
\hline \multirow{2}{*}{ Item (Days) } & \multicolumn{4}{c}{ Treatments } \\
\cline { 2 - 5 } & $\mathrm{T} 1$ & $\mathrm{~T} 2$ & $\mathrm{~T} 3$ & $\mathrm{~T} 4$ \\
\hline $0-15$ & $12.29 \pm 1.50$ & $8.29 \pm 1.02$ & $9.07 \pm 0.79$ & $8.73 \pm 0.79$ \\
$16-30$ & $10.44 \pm 1.33$ & $8.40 \pm 1.17$ & $7.96 \pm 0.59$ & $7.99 \pm 0.57$ \\
$31-45$ & $10.20 \pm 0.80$ & $9.52 \pm 0.65$ & $8.77 \pm 0.67$ & $8.17 \pm 0.34$ \\
$46-60$ & $10.37 \pm 0.78$ & $10.12 \pm 0.91$ & $9.78 \pm 0.47$ & $8.43 \pm 0.31$ \\
$61-75$ & $11.08 \pm 1.47$ & $9.83 \pm 0.69$ & $9.99 \pm 0.39$ & $8.48 \pm 0.42$ \\
Average & $10.88^{\mathrm{A}}$ & $9.23^{\mathrm{B}}$ & $9.11^{\mathrm{B}}$ & $8.36^{\mathrm{B}}$ \\
\hline
\end{tabular}

T1; Control, T2; Control plus $1.5 \mathrm{ml}$ orally dose of ZL/head/day, T3; Control plus $2.5 \mathrm{ml}$ orally dose of ZL/head/day and T4; Control plus $4 \mathrm{ml}$ orally dose of ZL/head/day. $Z L=Z A D$ liquid.

$A$ and $B$ Means of treatments within the same row with different superscript letters are significantly different $(P \leq 0.05)$.

These finding are agreement with those reported by Robinson (2002) who found that probiotics improved feed conversion ratio in small ruminants. In addition to Abdelrahman and Hunaiti (2008) pointed that using probiotics containing yeast in lamb's rations caused improved feed conversion ratio, which is due to the probiotics effect on rise the amount of cellulose degrading bacteria in the rumen of lambs fed with probiotics.

\section{CONCLUSION}

The present study clearly indicated that using ZAD in liquid form (ZL) as a probiotic improved digestibility coefficients and ruminal fermentation parameters. Also, led to increase dry matter intake and was accompanied by increased average daily growth, total gain and generally improve feed efficiency. However, more studies are required to investigate the effect of ZAD as a probiotic on physiological and productive response of sheep.

\section{REFERENCES}

Abbas, M. R.(2005). Effect of adding Iraqi probiotic to the ration on the productive performance of caged laying hens. Iraqi. J. Agri., 36, (6): 97-104.

Abd El-Ghani AA (2004). Influence of diet supplementation with yeast (Saccharomyces cerevisiae) on performance of Zaraibi goats. Small Rumin. Res., 52:223-229.

Abdelrahman MM, Hunaiti DA (2008). The effect of dietary yeast and protected methionine on performance and trace minerals status of growing Awassi lambs. Livest. Sci. 115:235-241.

Abdou .M.M (2001). Effect of some medicinal plants in the ration on productive performance of lactating animals. Ph. D. Thesis, Fac. of Agric. Ain Shams Univ. Cairo, Egypt.

Abo El-Nor SAH, Kholif MA (1998). Effect of supplementation of live yeast culture in the diet on the productive performance of lactating buffaloes. Milchwissenschaft 53: 663-666.

Adesogan, A. T. (2005). Improving forage quality and animal performance with fibrolytic enzymes. $\begin{array}{lllll}\text { Florida Ruminants } & \text { Nutrition } & \text { Symposium, } & \text { pp: }\end{array}$ http://dairy.ifas.ufl.edu/rns/2005/Adesogan.pdf

Ali, M. (2005). Effect of probiotic addition on growth performance of growing lambs fed different roughages. Egyptian J. Nutr. and Feeds,8: 567-578.

Antunovic Z, Speranda M, Amidzic D, Seric V, Steiner Z, Doma-Cinovic N, Boli F (2006). Probiotic application in lambs nutrition. Krmiva. 4:175-180.

AOAC (1995). Official methods of analysis. 15th ed. Association of Official Analytical Chemists. Arlongton, Virginiall USA. 
Armstrong, W. D and C. W. Carr (1964). Physiological chemistry 3rd ed. P, 75.Burges Publishing Co. Minneapolis, Minnesota.

Bactizad (2018). http://www.bactizad.com

Baraghit, G. A.; Ahmed, B. M.; Shehata, A. F. and Taie, H.T. (1995). Effect of clover intake by sheep and Assaf lambs on digestion Kinetics. Proc.5th. Sci. Conf. Animal Nutrition, Ismailia, Egypt, 356 p.

Blummel, M., H. Steingas and K.Becker (1997). The relationship between in vitro gas production, in vitro microbial biomass yield and $\mathrm{N}$ incorporation and its implications for the prediction of voluntary feed intake of roughages. British J. Nutr., 77: 911-921.

Bohm J. and A. Srour (1995). An Austrian probiotic feed additive for Egyptian buffalo and cattle production. 3rd Scientific Conference, Faculty of Veterinary Medicine, Assiut University (Egypt Society for Cattle Diseases), Dec 3-5, Assiut, Egypt.

Chademana, I. and Offer N. W. (1990). The effect of dietary inclusion of yeast culture on digestion in the sheep. J Anim Prod 50(3): 483-489.

Conway, E.J., (1957). Microdiffusion analysis and volumetric errors.,2 .Ed.,London Crosby-Lockwood nd and Son. Lt..

Cross, M. L. (2002). Microbes versus microbes: immune signals generated by probiotic lactobacilli and their role in protection against microbial pathogens. FEMS Immunol Med Microbiol 34(4): 245-253.

Doumas, B; W. Wabson and H. Biggs (1971). Albumin standards and measurement of serum with bromocresol green, clin. Chem..Acta., 31:87.Duncan David B. (1955). Multiple range and multiple F test . Biometric, 11: 1-42.

Duncan David B. (1955). Multiple range and multiple F test . Biometric, 11: 1-42.

Elghandour M.M.Y., J.C. Vázquez Chagoyán, A.Z.M. Salem, A.E. Kholif, J.S. MartínezCastañeda, L.M. Camacho and M.A. Cerrillo-Soto (2014). Effects of Saccharomyces cerevisiae at direct addition or pre-incubation on In vitro gas production kinetics and degradability of four fibrous feeds. Ital. J.Anim. Sci. 13:295-301.

El-Hosseiny, Hoda, M.; Kh. M. M. Mousa; H. B. AbouElella and O. A. Alama (2008). Influence of some mineral additives on nutrients digestibility, performance and economic efficiency of growing camel young feed dietary silage. Proe. Of Middle East.

El-Shaer, E.K.H. (2003). Nutritional studies in ruminants (Effect of yeast culture supplementation and concentrate : roughage ratio on performance of growing lambs).Ph.D.Thesis Faculty of Agriculture , Mansoura University.Egypt.

Erasmus, LJ, P.M. Botha, A. Kistner (1992). Effect of yeast culture supplement on production, rumen fermentation and duodenal nitrogen flow in dairy cows. J. Dairy Sci. 75:3056-3065.

FAO/WHO (2002). Report of a joint FAO/WHO expert consultation on guidelines for the evaluation of probiotics in food. London, Ontario, Canada: World Health Organization and Food Agriculture Organization of the United Nations.

Fassati, P. and L. Principe (1982). Measurement triglyceride. Clin . Chem., 28: 2077

Fuller, R. (1977). The importance of lactobacilli in maintaining normal microbial balance. British Poultry Science, 18:85.

Gado, H. M., A. Z. M. Salem (2008). Influence of exogenous enzymes from anaerobic source on growth performance, digestibility, ruminal fermentation and blood metabolites in lambs fed on orange pulp silage in total mixed ration. Proceedings of the 59th Annual Meeting of the European Association for Animal Production, August 24-27, 2008 Vilnius, Lithuania, pp: 228-230.

Gado, H. M., A. Z. M. Salem, P. H. Robinson and M. Hassan (2009). Influence of exogenous enzymes on nutrient digestibility, extent of ruminal fermentation as well as milk production and composition in dairy cows. Anim. Feed Sci. Technol., 154: 36-46. 
Gado, H. M., F. Ramadan, M. Mourad and B B. Matter (2007). Effect of biological treatments of some agricultural by-products on ration digestibility and lamb performance. Egypt. J. Nutr. Feeds, 10: 509-516.

Galyean, M. L., G. A. Nunnery, P. J. Defoor, G. B. Salyer, and C. H. Parsons. (2000). Effects of live cultures of Lactobacillus acidophilus (Strains 45 and 51) and Propionibacteriumfreudenreichii PF-24 on performance and carcass characteristics of finishing beef steers. Burnett Center Internet Prog. Rep. No. 8, Texas Tech Univ., http://www. depts.ttu.edu/ afs/burnett_center / progress_reports/.

Getachew, G.;H. P. S. Makkar and K. Becker. (2002). Tropical browses: Contents of phenolics compounds, In vitro gas production and stoichiometric relationship between short chain fatty acid and In vitro gas production. J. Agric.Sci., 139: 341-352.

Giraldo, L.A., M.L. Tejido, M.J. Ranilla, M.D. Carro (2008). Effects of exogenous fibrolytic enzymes on in vitro ruminal fermentation of substrates with different forage:concentrate ratios. Anim. Feed Sci. Technol. 141, 306-325.

Gomez-Basauri, J.;M. B. de Ondarza and J. SicilianoJones.(2001). Intake and milk production of dairy cows fed lactic acid bacteria and mannanoligosaccharide.J. Dairy Sci. 84(Suppl. 1):283..

Hassan. S. A. and K. M. Hassan (2008). The effect of supplementation of medicinal plants and probiotic on growth rate and blood parameters of karadi lambs. Egyption, J. of Nutr - and Feed. 12 (1): 53-63.

Hentages, D. J. (1993). Role of the intestinal microflora in host defense against infection. In human intestinal microflora in health and diseases ed. Hentages, D. J. Ch. 14, pp. 311-331. New York: Academic press.

Hristov, A.N., J. Oh, J.L. Firkins, J. Dijkstra, E. Kebreab, G. Waghorn, H.P. Makkar, A.T. Adesogan, W. Yang and C. Lee (2013). Special topics: mitigation of methane and nitrous oxide emissions from animal operations: I. A review of enteric methane mitigation options. J. Anim. Sci., 91:5045-5069.

Husdan, H. (1968). Chemical determination of creatinine with depproteinization. Clin. Chem., 14:222.

Hutjens, M.F. (2005). Dairy Efficiency and Dry Matter Intake.University of Illinois 232 ASL, 1207 W. Gregory Drive, Urbana, IL 61801.

Isolauri, E., Y. Sutas, P. Kankaanpaa, H. Arvilommi, S. Salminen (2001). Probiotics: Effects on immunity. Am. J. Clin. Nutr. 73:444-450.

Jang D, Oh Y, KyongPiao H, Guo Choi L, Bong Yun H, Hyeon Kim J, Yong Y (2009). Evaluation of Probiotics as an Alternative to Antibiotic on Growth Performance, Nutrient Digestibility, Occurrence of Diarrhea and Immune Response in Weaning Pigs. J. Anim. Sci. Tech. 51:751-759.

Khalid, M.F., M.A. Shahzad, M. Sarwar, A.U. Rehman, M. Sharif, N. Mukhtar (2011). Probiotics and lamb performance: A review. Afr. J. Agric. Res. 6(23):5198-5203

Kholif, S.M. (2006). Effect of improving the nutritional value poor quality roughages on the yield and composition of goat's milk. Egypt. J. Dairy Sci., 34:197-205.

Kholif, S.M., H. Gado, T.A. Morsy, N. El-Bordeny and A.A. Abedo (2012). Influence of exogenous enzymes on nutrient digestibility, blood composition, milk production and its composition as well as milk fatty acids profile in dairy buffaloes. Egypt. J. Nutr. Feeds, 15: 13-22.

Krehbiel, C.R.; S.R. Rust; G. Zhang and S.E. Gilliland (2003). Bacterial direct-fed Use of commercial Probiotics supplement in meat goat. J. Anim. Sci.,87: 723-728.

Krueger, N. A., A. T. Adesogan, C. R. Staples, W. A. Krueger, S. C. Kim, R. C. Little, and L. E. Sollenberger (2008). Effect of method of applying fibrolytic enzymes or ammonia to Bermuda grass hay on feed intake, digestion and growth of beef steers. J. Anim. Sci., 86:882-889.

March, W. (1965). Clin. Chem., 11. 624(Pp 967-973)

Menke, H.H. and H. Steingass (1988). Estimation of the energetic feed value obtained from chemical analysis and In vitro gas production using rumen fluid. Anim. Res. Dev., 28: 7-55. 
Monika, S., K. Umesh, V.K. Sareen, S. Singh (2000). Effect of yeast culture (YEASACC1026) supplement on fermentation and in sacco digestibility of some roughages in buffalo calves Indian. $\mathbf{J}$ of AnimSci 70: 289-293.

Morgavi, D.P., K.A. Beauchemin, V.L. Nsereko, L.M. Rode, M. McAllister, Y. Wang (2000). A trichoderma feed enzyme preparation enhances adhesion of Fibrobacter succinogenes to complex substrates but not to pure cellulose. In: 25th Conf. Rumen Function, Chicago, IL, USA, p. 33.

Mukhtar, N., M. Sarwar, M.U. Nisa and M.A. Sheikh (2010). Growth response of growing lambs fed on concentrate with or without ionophores and probiotics. Int. J. Agric. Biol., 12: 734-738.

Nocek, J.E., W.P. Kautz, J.A.Z. Leedle and E. Block (2003). Direct-fed microbial supplementation on the performance of dairy cattle during the transition period. J. Dairy Sci. 86(1):331-335.

NRC (1985). Nutrient Requirements of Sheep. 6th ed. National Research Council. National Academy Press. Washington, D. C., USA.

Nsereko, V.L., D.P. Morgavi, L.M. Rode, K.A. Beauchemin, T.A. McAllister (2000). Effects of fungal enzyme preparations on hydrolysis and subsequent degradation of alfalfa hay fiber by mixed rumen microorganisms in vitro. Anim. Feed Sci. Technol. 88, 153-170.

Orr, C. L.; D. R. Ware;E. T. Manfi-edi and D. P. Hutheson(1988). The effect of continuous feeding of Lactobacillus acidophilus strain BT1386 on gain and feed efficiency of feeder calves. J. Anim. Sci. 66(Suppl. 1):460-461. (Abstr.)

Reitman, S. and S. Frankel (1957).Calorimetric method for the determination of serum glutamicoxaloacetic and glutamic- pyruvate transeaminase. An.J. Clin.Path. 28:56.

Robinson, P. H. (2002). Yeast products for growing and lactating dairy cattle: Impact on rumen fermentation and performance. Dairy Rev 9: 1-4.

Russell, J.B. and D.B. Wilson (1996). Why are ruminal cellulolytic bacteria unable to digest cellulose at low pH? J. Dairy Sci. 79:1503-1510.

Sarwar, M., N. Mukhtar, M.A. Shehzad and M. Nisa (2010). Traditional versus high input feeding system: Impact on nutrients intake, blood dynamics, hormonal profile, weight gain and economics in growing lambs. Egy. J. Sheep Goat Sci., 5: 127-145.

SAS (2001). Statistical Analysis System guide: Version 8.2th. Institute Inc. Cary. Nc. USA.

Soliman, S. M. ; A. M. El-Shinnawy and A. M. El-Morsy (2016). Effect of Probiotic or Prebiotic Supplementation on the Productive Performance of Barki Lambs. J.Animal and Poultry Prod., Mansoura Univ., Vol.7(10): 369- 376.

Szumacher-Strabel, M.; A. Potkanski; J .Kowalczyk; A. Cieslak; M. Czauderna; M .Gubala and P. Jedroszkowiak (2002). The influence of supplemental fat on rumen volatile fatty acid profile, ammonia and $\mathrm{pH}$ level in sheep fed a standard diet. Journal of Animal and Feed Sciences, 11(4):577587.

Tripathi, M.K. and S.A. Karim (2011). Effect of yeast cultures supplementation on live weight change, rumen fermentation, ciliate protozoa population, microbial hydrolytic enzymes status and slaughtering performance of growing lamb. J. Livestc. Sci. 135: 17-25.

Umesb, P. C. P. (1999). Probiotics benefits. Poultry International 38(12):40-44.

Warner, A.C.I., (1964). Production of volatile fatty acidsintherumen:methodsof measurements. Nutr. Abst. Rev., 34: 339.

Wathins, B. A. (1982). In vivo inhibitory effects of lacidophilus against pathogenic E. Coli in gnotobiotic chicks. Poultry Sci., 61:1298-1308.

Yang, W. Z., K. A. Beauchemin and L. M. Rody (1999). Effect of an enzyme feed additive on extent of digestion and milk production of lactating dairy cows. J. Dairy Sci., 82: 391-403. 


\title{
تأثير إضافة إنزيمات خارجية علي الهضم معمليًا والأداء الإنتاجي في الأغنام
}

\author{
أحمد عبد الله مروان و وعبد الله منصور سنجر2

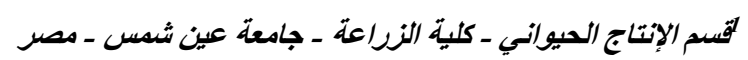

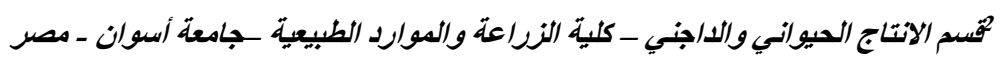

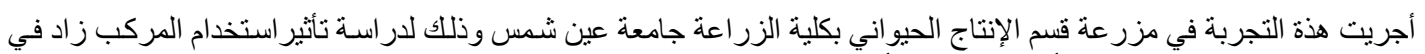

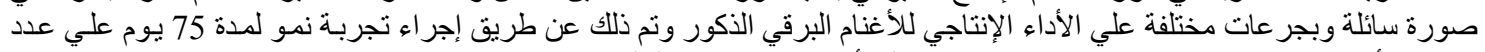

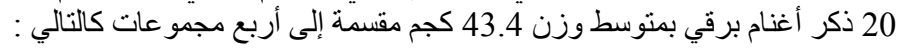

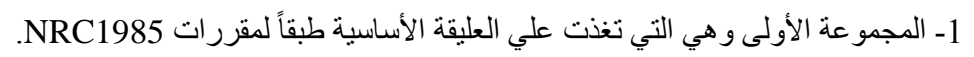

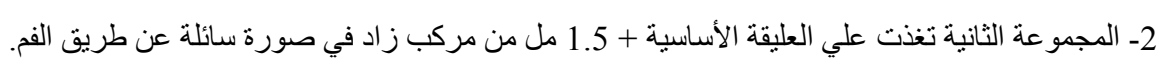

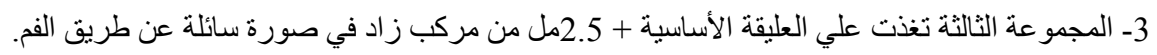

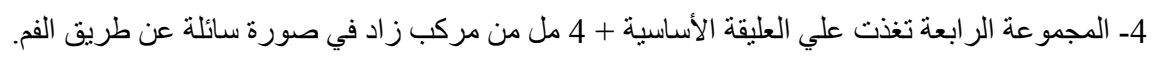

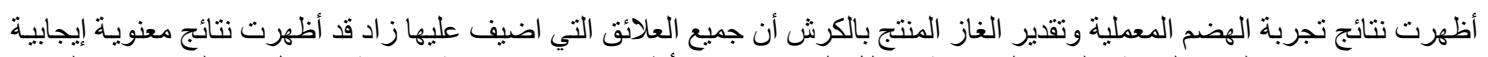

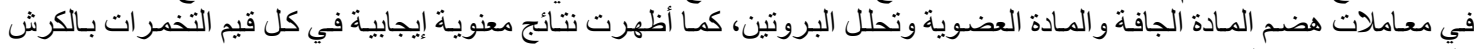
بالمقارنة بمجموعة المقارنة.

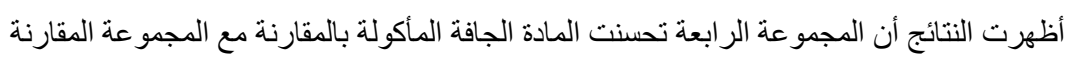

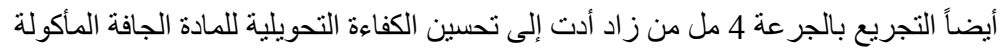

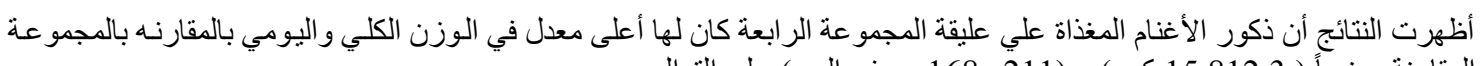

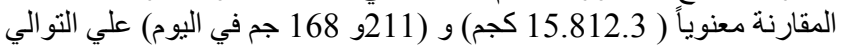

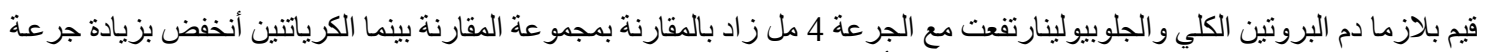

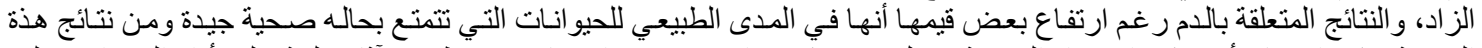
التجربة يمكن استتناج أنه يمكن استخدام الجرعة 4 مل من مركب زاد في علائق الاغنام بدون ظهور آثارسلبية علي أداء الحيوان وعلى لئى 